\title{
Pedological Survey and Aspects Regarding the Use and Occupation of the River Itacolomi Hidrographical Sub-Basin in Ceará
}

\author{
Livana Sousa Guimarães \\ Mestranda em Geografia \\ Universidade Estadual Vale do Acaraú-UVA \\ Ernane Cortez lima \\ Professor Dr. do Curso de Geografia \\ Universidade Estadual Vale do Acaraú-UVA
}

\begin{abstract}
This work seeks to conduct a survey about the principal types of soils, as well as to identify different forms of use and occupation ofthe river Itacolomi hydrographical sub-basin. The area under consideration, what is part of the river Coreaú hydrographical sub-basin, covers a territorial extension of about $1065 \mathrm{~km}^{2}$ and is inserted into the municipalities of Tianguá, Viçosa do Ceará, Granja and Meruoca. The methodology is based upon the general system theory, which is grounded in systems analysis. Furthermore, geo-mapping charts suited to that sub-basin were drawn up along with the conduction of field and bibliographical surveys. From this point of view, it must be stressed that such sub-basin has unique levels of environmental degradation due to the presence of partially unspoiled areas that present humid segments besides totally debased areas. In this manner, it is realized that the process of use and occupation of that sub-basin is tied to the extensive stockbreeding, subsistence farming, deforestation and fires, which plays a significant role in the intensification in erosive processes and loss of soils.
\end{abstract}

Keywords: Hydric Resources; Degradation; Subsistence Farming.

\section{Introduction}

The Brazilian semi-arid region has specific characteristics that differentiate itself from other regions since it has been presenting irregularity in precipitation level over the years besides high temperatures, the presence of shallow soils, acaatinga prevailing vegetation and the possession of intermittent rivers (AB'SÁBER, 1999). In this respect, the conduction of studies toward the recognition of that area is extremely essential, in particular, those that are related to hydrographical sub-basins.

In this sense, studies incorporated in hydrographical sub-basins are had as alternatives to ensure better living conditions with more suitable techniques concerning the use and occupation of soils. This way, Rodrigues (2016), stresses that those hydrographical sub-basins which are had as territorial units make possible an integrated analysis of natural, social and economic elements. In addition to it, Rodrigues and Lima (2015, p.61) highlight that "hydrographical sub-basins became an essential spatial analysis unit".

Therefore, a soil survey and an analysis of its use and occupation were carried out, taking into consideration the Itacolomi river hydrographical sub-basin. In this light, it was sought to conduct a diagnosis of the soil types and the impacts which this area has undergone.

The Itacolomi river hydrographical sub-basin is located in the Northwest region of Ceara and, according to SUDENE/DGS, its cartographical points areSA.24-Y-C-V (Viçosa do Ceará), SA.24-Y-C-III (Granja), SA.24-YC-VI (Frecheirinha) and SA.24-Y-C-II (Chaval), what corresponds to an extension of about $1065 \mathrm{~km}^{2}$ and composes the Coreaú river hydrographical sub-basin system. The object of analysis drains part of the municipalities of Tianguá, Viçosa do Ceará, Granja and Uruoca.

In this context, the Itacolomi river hydrographical sub-basin displays a unique dynamism originated from the junction of physical and environmental elements that make it up. 

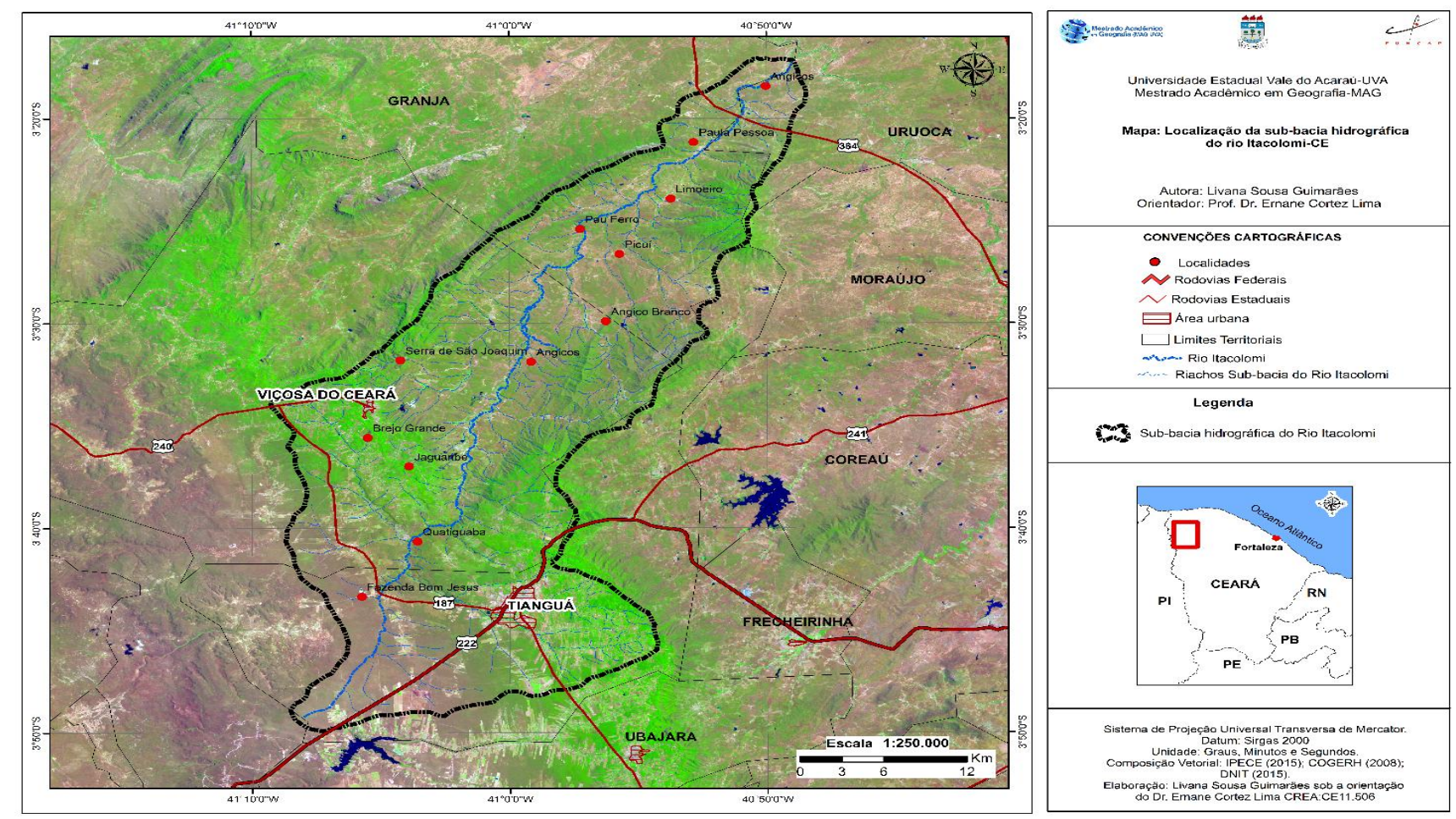

Figure 1: Itacolomi river hydrographical sub-basin location map. (Guimarães 2018)

Having its springs in Ibiapaba plateau, which is formed by sedimentary rocks, it flows into the Coreaú river hydrographical sub-basin, what is an attribution of the sertaneja depressionor pediplain, and provides a significant landscape diversity represented in its vegetation, soil and hydric resources formation as well as in its geological and geomorphological aspects. The Itacolomi river has some creeks in its network which ranges between the $1^{\text {st }}$ and $5^{\text {th }}$ order in accordance with the Stralher fluvial hierarchy (1952). (Observe figure 1)

\section{Development}

\subsection{Methodological procedures}

The methodological theoretical conception, what has guided this research, refers to the employment of system analysis, which is grounded in theLudwig von Bertalanffy's general system theory (1975),turned to the landscape analysis once that area has a great territorial extension and unique forms of use and occupation along its hydrographical system.

As regards the cartographical conventions used to draw up the location and soils maps, vectorial records were adjusted to the sub-basin. Rivers and creeks data were made available by the Companhia de Gestão de Recursos Hídricos(COGERH) (Hydric Resources Management Company), the municipalities boundaries, towns and highways were provided by the Instituto Brasileiro de Geografia e Estatísticas (IBGE) (Geography and Statistics Brazilian Institute), the Instituto de Pesquisa e Estratégia Econômica do Ceará (IPECE) (Institute of Surveys and Economical Strategy of Ceará) and the Empresa Brasileira de Pesquisa Agropecuária(EMBRAPA) (Brazilian Company for Stockbreeding Research).

In order to demarcate the Itacolomi river sub-basin polygon, geoprocessing techniques were used through the automatic demarcation technique using SRTM (Shuttle Radar Topography Mission) radar images, a device which was provided by EMBRAPA and whose working is given by satellite monitoring in GeoTIFF format.

As stated by Rodrigues (2016, p. 42), firstly the drainage is removed with the aid of tools so the flux direction can be recognized, "the flux gathered in each cell, the longest flux trajectory and the numerical order to each segment". After that, a drainage bitmapshapefile is generated soon after a drainage shaping and, lastly, the sub-basin is demarcated from a collection point. Having these steps been carried out, the bitmap shapefile is converted into a polygon vector shapefile.

For the recognition of soils present in that area, the Sistema Brasileiro de Classificação de Solos (SIBCS)(Brazilian System for Soils Classification) was used, which was produced by EMBRAPA (2013) and facilitated the production of a map of the analyzed area. 


\subsection{Results and discussion}

The results were obtained from the approached methodology, which was based on the study of natural elements from the Itacolomi river hydrographical sub-basin. This way, a natural elements characterization - like geology, geomorphology, climate, vegetation - was conducted, in particular in soils from that sub-basin area. Such characterization and analysis were possible only after a geo-mapping survey of that area.

As regards the soil types that correspond to the Itacolomi river hydrographical sub-basin area, they were identified not only through the Sistema Brasileiro de Classificação de Solos (SIBCS), but also through a morphological investigation conducted during fieldworks.

The Planosols present in the northern part of that sub-basin are characterized by presenting A and $\mathrm{E}$ horizons with a medium or clayey texture and also a sandy texture over a Bt horizon. They are typical soils for slightly wavy and plane reliefs, which are commonly, found occupying the lowest parts of Pediplains and Floodplains in semi-arid regions. It was found the presence of Planosols, which are characteristics for slightly wavy and plane reliefs and typical of semi-arid regions that occupy the lowest parts of Pediplains and Floodplains (Pereira e Silva, 2007).

Litholic Neosols are characterized by their weak pedological evolution, shallow sandy texture, A horizon followed by the $\mathrm{C}$ or over the rock $-\mathrm{R}$, stoniness in their surfaces, in which are frequently found linked to rocky outcrops and present in Pediplains. Furthermore, they present strong limitations regarding their use in agriculture once they are susceptible to erosion, stoniness and rockiness.

Fluvic Neosols are deep soils that are originated from the Holocene fluvial sedimentation and present A and C horizons. Once they are considered as soils of high agricultural potentiality and with high natural fertility, they are largely used with irrigation systems and are made up of non-consolidated clayey, silty and sandy sediments, which is a characteristic for alluvial plains.

The Red-Yellow Latosols are had as the oldest soils in Ceará and are in general constituted of sandstone materials from the Cretaceous epoch and also of sand-clayey sediments of the Formação Barreiras (Tableland or Plateau, Barrier Formation) from the Miocene and Pleistocene epochs. They have colors ranging between red and yellow, are deep and quite weathered and are found in sedimentary areas like in the Ibiapaba plateau. In addition, they present A, B and C horizons, which are slightly different and have almost uniform clay levels.

The Red-Yellow Argisols are featured by their great deepness, A, Bt and $\mathrm{C}$ horizons, medium clayey texture, having the $\mathrm{B}$ horizon higher levels of clay in comparison to the A horizon, what implies in a notorious difference between both textures. They are originated from different types of materials, from sand-clayey sediments of Formação Barreiras (Miocene and Pleistocene) to alterations in different kinds of crystalline rocks (Precambrian).

Therefore, the soil map (figure 2) below is presented as a way to deliver a better comprehension of the types of soils which make up that sub-basin. Adapted data from EMBRAPA (2013) was in order to produce this map.

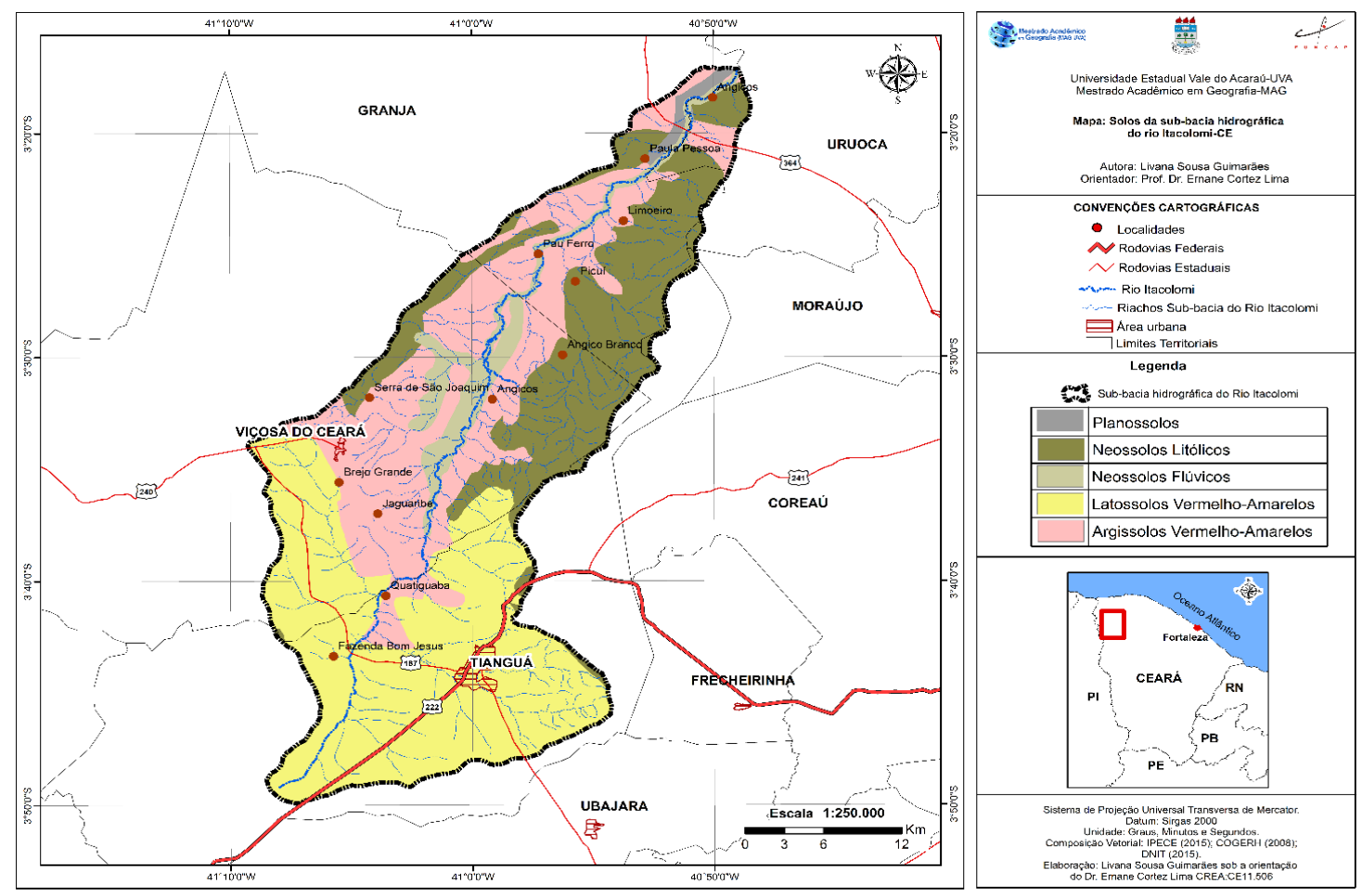

Figure 2: Itacolomi river hydrographical sub-basin soil map. (Guimarães 2018) 
From this view, it must be highlighted that the Itacolomi river hydrographical sub-basin presents, in pedological terms, a diversified soil patchwork in which they have dominant characteristics besides limitations regarding their use since they are not related to differentiated reliefs. Thus, these soils are handled accordingly to their fertility and used mainly for subsistence farming in the planting of corn, beans, banana and vegetables, which are grown close to hydric resources since the predominant soils in this kind of area are Fluvic Neosolsandthey possess a medium or high natural fertility. (Observe table 1)

Table 1: Characteristics of soils present in the Itacolomi river hydrographical sub-basin (Guimarães 2018).

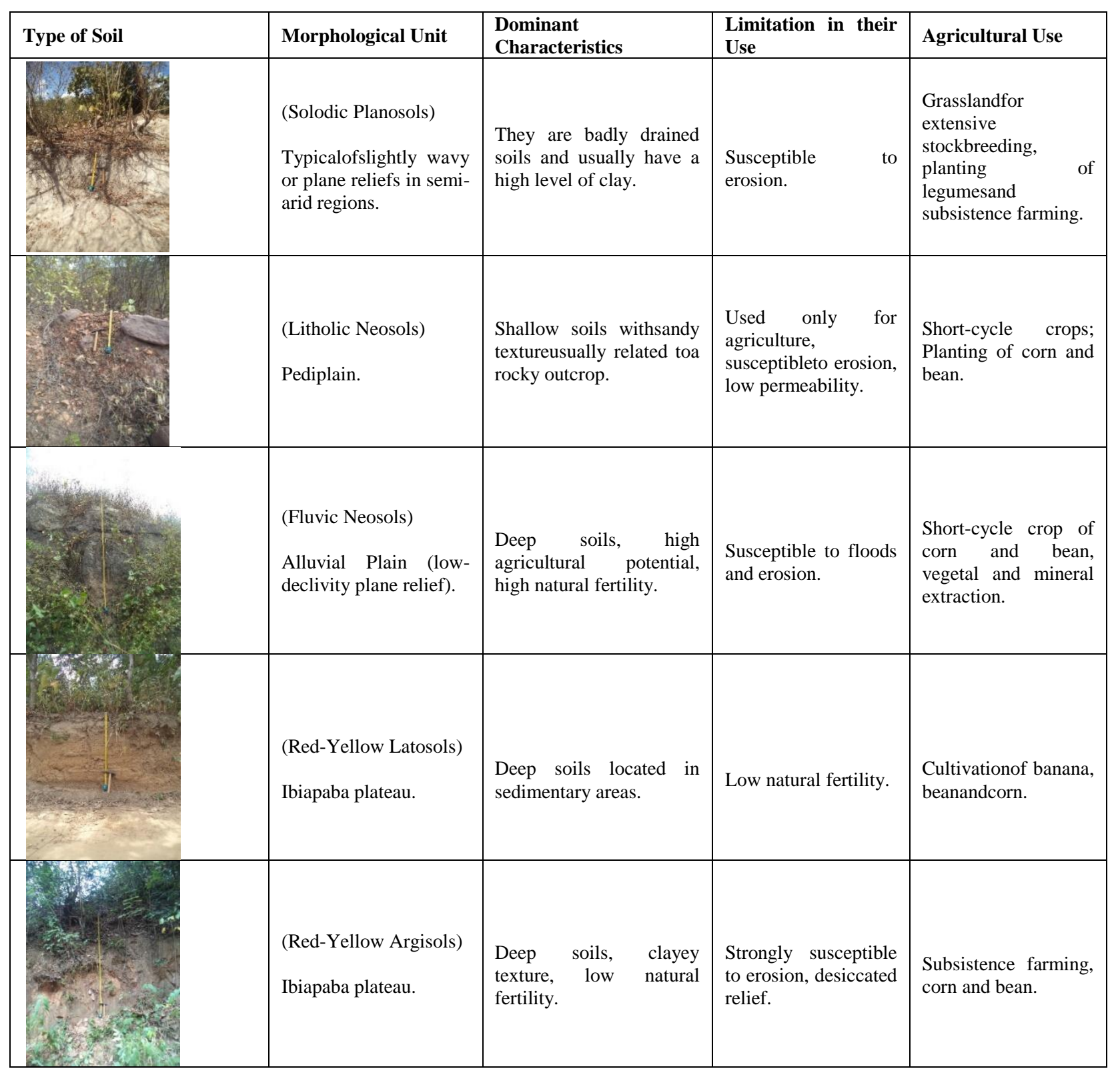

\section{Aspects of the use and occupation in the itacolomi river hydrographycal sub-basin}

In Zanella's view (2007), natural resources in Ceará have been suffering lots of changes due to a continued expansion of productive activities performed by anthropic actions. It is also stated that one of the principal problems concerning the hydric resources degradation is tied to the pollution caused by domestic and industrial sewage, which are dumped into waterways without being previously treated. Thus, studying hydrographical basins becomes meaningful since they deliver a more systematic knowledge that can be employed in environmental plans of these areas.

For Nascimento (2010), the environmental degradation process is a result more of socioeconomic and cultural interventions than environmental factors in their own dynamism. Furthermore, the non-observance of policies regarding territorial management and conservationist practices of use and occupation of lands are liable to generate environmental deterioration problems once they jeopardize the soil production capacity and, consequently, its environmental quality. 
After the fieldwork, it was verified that the use and occupation in that sub-basin resulted from the existence of two important urban centers in the region, namely Tianguá and Viçosa do Ceará, in addition to towns situated close to creeks making up the area.In this manner, it was noticed that thearea is used for stockbreeding, which causes compression on the soil and the removal of the ground cover. (Figure 3)

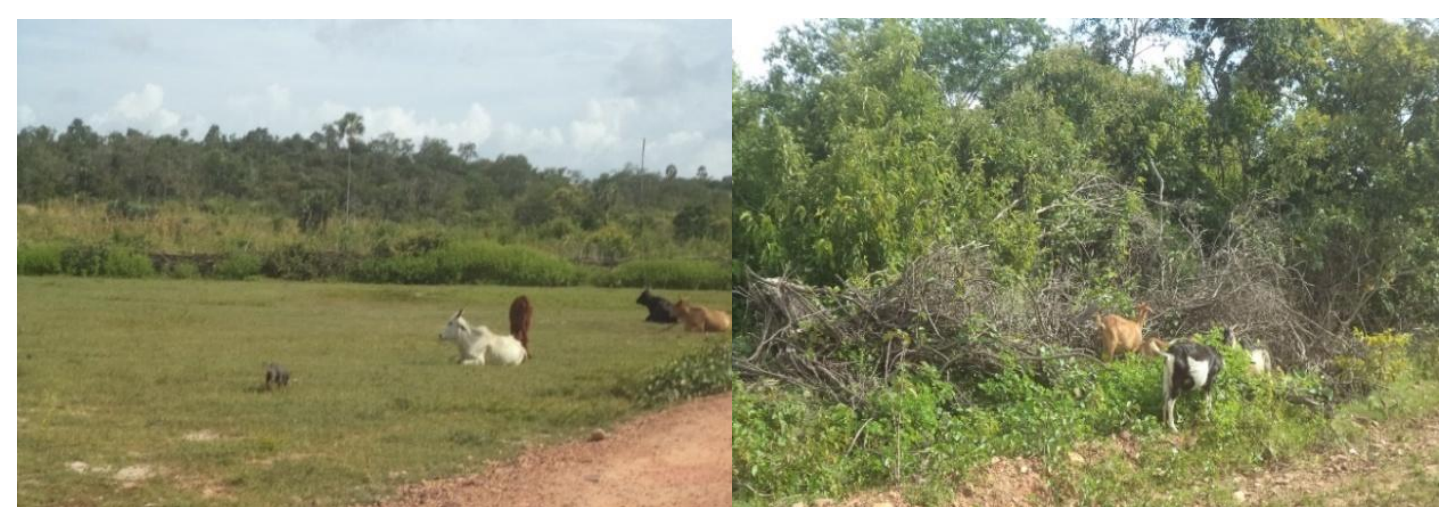

Figure 3: Areas used for stockbreeding (Guimarães 2018)

In this regard, in the Lajes creek, which is close to Sierra Dom Simão, the ciliary forest is partially preserved with the existence of carnaúba (Coperniciaprunifera), oiticica (Licaniarigida) and mofumbo (Combretumleprosum). There is considerable gravel transportation with a $20-30 \mathrm{~cm}$ of diameter at the bottom of the creek bed, what means a more effective flow of it.

In the Itacolomi river hydrographical sub-basin, it is possible to go over the use of it in subsistence farming practices with the use of quite rudimentary techniques such as vegetation removal soon after burning and, after that, the place is used to grow corn, bean and cassava. Another problem worthy of mentioning is the indiscriminate deforestation, which in accordance with Souza (2000), compromise seriously the soil production capacity. For Pereira and Silva (2005), fires constitute one of the main offending agents for the soil. (Figure 4)

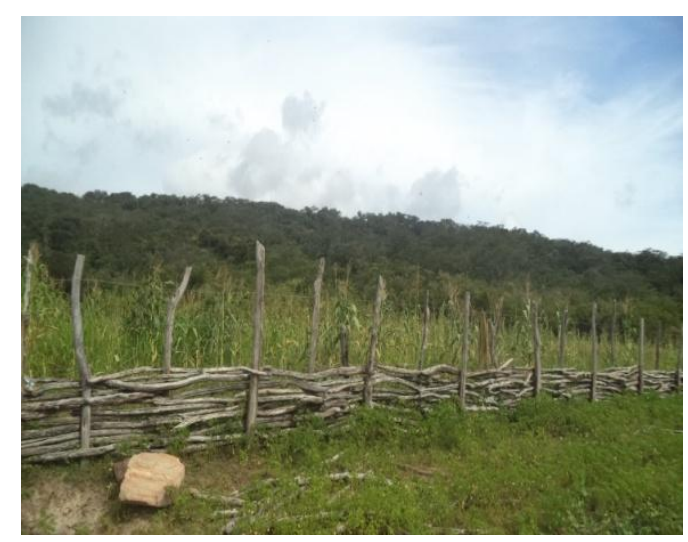

Figure 4: A cornfield in the area. (Guimarães 2018)

The Frecheirinha creek is also notorious due to the total disfigurement of its ciliary forest in reason of a road that was built removing its whole vegetation, however, it is possible to see close to the creek a sugarcane plantation. (Figure 5) 


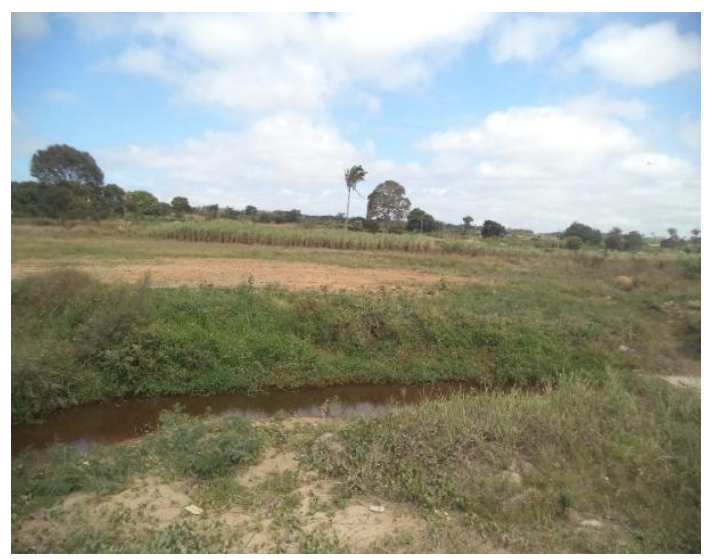

Figure 5:Frecheirinha creek. (Guimarães 2018)

It is noteworthy that the principal forms of use and occupation in that sub-basin are tied to an extensive stockbreeding, subsistence farming, deforestation and fires, which plays a considerable role in the intensification of erosive processes.

\section{Final considerations}

The Itacolomi river hydrographical sub-basin is had as an important hydrographical system in the northwestern region of Ceará, which has been suffering environmental degradation processes related to the indiscriminate use of natural resources due to anthropic activities.

The intense use of natural resources by men can lead to serious impacts in the environment. Therefore, as a result of such acute exploitation of natural resources, it extremely essential to study hydrographical sub-basins. Such resources are limited and, for this reason, it is necessary to propose measures to ease or reduce the impacts caused by anthropic actions that result in a disfiguration of landscapes.

In this view, the Itacolomi river hydrographical sub-basin has a rich landscape diversity, but along the years it has been suffering changes caused by anthropic actions such as the vegetation removal to subsistence farming and the use of those areas for stockbreeding, what makes necessary a reassessment of the environmental potentialities to a proper handling of this environment.

\section{Acknowledgements}

To FUNCAP bygranting e promotingscholarships, to Universidade Estadual Vale do Acaraú - UVA (Vale do Acaraú StateUniversity).

\section{References}

Ab'Sáber, A. N. Sertão and Sertanejos: A PainfulHumanGeography(Sertões e sertanejos: Uma Geografia Humana Sofrida). In: Dossiê Nordeste Seco. São Paulo/SP, AdvancedStudies Magazine (Revista Estudos Avançados)/USP, Vol. 13 - No 36 - May/August 1999, p.7-59.

Bandeira, R; Claudino-Sales, V.The Geomorphological Apescts Relation and the Use of the Geographical Space in Sierra Ubajara, Ibiapaba Plateau, Ceará.(Relação dos Aspectos Geomorfológicos e o Uso do Espaço Geografico na Serra de Ubajara, Planalto da Ibiapaba, Ceará).In: XIII Applied Physical Geography National Symposium, 2009, Viçosa. MG. Annalsof the XIII Applied Physical Geography National Symposium, 2009. v. 1. p. 1-18.

Claudino-Sales, V. The Megageomorphology of Ceará.(Megageomorfologia do Estado do Ceara). 1. ed. São Paulo: NewAcademicEditions, 2016. v. 1. p. 90.

EMBRAPA. Brazilian System for SoilsClassification(Sistema Brasileiro de Classificação de Solos). 2. ed. Rio de Janeiro: Embrapa Solos, 2013. 306 p.

Fernandes, A. PhytogeographicalTopics(Temas fitogeográficos). Fortaleza: Stylus Comunicações, 1990. p.116.

Guimarães, L. S.; Lima, E. C. GeoenvironmentalSurveyof Natural PhysicalComponents in theBrazilianNortheastSemi-AridHydrographicalSub-Basin, Itacolomi River/Ceará (Levantamento Geoambiental dos Componentes Físico-Naturais da Sub-Bacia Hidrográfica Semiárida do Nordeste do Brasil, Rio Itacolomi-CE). GeographyHouse's Magazine of Sobral (Revista da Casa da Geografia de Sobral) (RCGS), v. 21, p. 1104-1118, 2019.

Lima, E. C. GeoenvironmentalAnalysisandHandling of the Acaraú River Spring: Sierra Matas(Análise e Manejo Geoambiental das Nascentes do Alto rio Acaraú: Serra das Matas Ceará). Master Thesis UECE, Fortaleza- 2004. 
Lima, E. C.; SILVA, E. V. GeosystemicStudiesAppliedtoHydrographicalBasins(Estudos Geossistêmicos Aplicados à Bacias Hidrográficas).Ecuador Magazine (Revista Equador), v. 4, p. 3-20, 2015.

Lima, E. C. Environmental Planning as a Tool for Environmental Management oftheDrainageBasinof Paulo SarasateReservoir Varjota-Ceará (Planejamento Ambiental como subsídio a Gestão Ambiental da Bacia de Drenagem do Açude Paulo Sarasate Varjota-Ceará).Thesis (GeographyGraduationProgram) FederalUniversityof Ceará (Universidade Federal do Ceará), UFC. Fortaleza, 2012. p. 201.

Nascimento, F. R. IntermittentandSeasonalHydrographicalBasinsandHydroenvironmentalPotentialities in theBrazilianNortheast(Bacias hidrográficas intermitentes sazonais e potencialidades hidroambientais no nordeste setentrional brasileiro). GEOgraphia, v. 16, n. 32, 2014, p.90117.Available at: <www.uff.br/geographia/ojs/index. php/geographia/article/view/718/488>. Acesso em: 10 Jun. 2018.

Pereira, R. C. M.; Silva, E. V. Ceará'sSoilsandVegetations: General Characteristics(Solos e vegetação do Ceará: Caracteristicas gerais). In: SILVA, J. B. Cavalcante, T. C.; Dantas, E. W. C.; Sousa, M. S.(Org.). Ceará: A New Geographycal Perspective (Ceará: um novo olhar geográfico). 2.ed. atual Fortaleza: Demócrito RochaEditions, 2007. p. 189-210.

Rodrigues, J. M. D. ; Lima, E. C. Environmental Systems Analysis in the Bom Jesus River Hydrographical Sub-Basin - Taperuaba - Ce.(Análise dos Sistemas Ambientais da Sub-Bacia Hidrográfica do Rio Bom Jesus - Taperuaba-Ce). GeographyHouse's Magazine of Sobral (Revista da Casa da Geografia de Sobral), v. 17, p. 60-79, 2015.

Rodrigues, J.M.D.; Lima, E. C.Environmental Systems Analysis in the Bom Jesus River HydrographicalSubBasin: Guidelines for Environmental Planning andManagemente(Análise dos Sistemas Ambientais da Sub-Bacia Hidrográfica do Rio Bom Jesus: Diretrizes para o Planejamento e Gestão Ambiental). Espaço Aberto (UFRJ), v. 6, p. 89-102, 2016.

Rodrigues, J. M. D. Environmental Systems Analysis in the Bom Jesus River HydrographicalSub-Basin, Taperuaba, Ceará, Brazil(Análise dos sistemas ambientais da Sub-bacia hidrográfica do rio Bom Jesus, Taperuaba, Ceará, Brasil).Geography Master Thesis. Vale do Acaraú StateUniversity(Universidade Estadual Vale do Acaraú). Sobral. 2016. p. 183.

Silva, D. P.;Lima, E. C . Environmental Impactsonthe Top Courseofthe Batateiras River HydrographicalSubBasin in the South Regionof Ceará (Impactos Ambientais no Alto Curso da sub-bacia Hidrográfica do Rio Batateiras na Região Sul do Estado do Ceará). GeographyHouse's Magazine of Sobral (Revista da Casa da Geografia de Sobral) (RCGS), v. 21, p. 1091-1103, 2019.

Souza, M. J. N. Natural Basis and the Geoenvironmental Zoning Sketch of Ceará (Bases naturais e esboço do zoneamento geoambiental do Estado do Ceará). In LIMA, L. C.; MORAIS, J. O.; SOUZA, M. J. N.Territorial Subdivisionand Regional Management in Ceará(Compartimentação Territorial e Gestão Regional do Ceará). Fortaleza: Edit. FUNCEME, 2000. p.5-104.

Souza, M. J. N. Geoenvironmental Subdivision in Ceará (Compartimentação geoambiental do Ceará).In:___ SILVA, J. B. CAVALCANTE, T. C.; DANTAS, E. W. C.; SOUSA, M. S.(Orgs).Ceará: A New Geographical Perspective (Ceará: um novo olhar geográfico). 2.ed. atual - Fortaleza: Demócrito RochaEditions, 2007. p.127-140.

Strahler, A. Hypsometric (area-altitude) analysis of erosional topography.Geol. Soc. América Bulletin, p -1142, 1952.

Zanella, M. E. Climatic Characteristics and Hydric Resources of Ceará (As características climáticas e os recursos hídricos do Ceará). In: SILVA, J. B. Cavalcante, T. C.; Dantas, E. W. C.; Sousa, M. S. (Orgs). Ceará: A New Geographical Perspective (Ceará: um novo olhar geográfico). 2.ed. atual - Fortaleza: Demócrito Rocha Editions, 2007. 480 p. 